\title{
The fundamental profile of winner and looser portfolios at Bovespa between 1995 and 2002
}

\author{
Luciano Martin Rostagno ${ }^{\dagger}$ \\ CM Capital Markets \\ Karina Talamini Costa Soares ${ }^{¥}$ \\ University do Vale do Rio dos Sinos - UNISINOS \\ Rodrigo Oliveira Soares $\Psi$ \\ University do Vale do Rio dos Sinos - UNISINOS
}

\begin{abstract}
The controversy involving the efficiency market hypothesis opens space to different proposals of how to evaluate assets, as well as the possibility of predicting stock returns. The empirical analysis conducted in this work follow the fundamental analysis rationale, where we seek to outline portfolio winners and losers profile traded at Bovespa from January of 1995 to December of 2002. We analyzed 37 variables in portfolios built based on monthly returns of stocks. Among the portfolios analyzed, the results pointed out to a better characterization of the profile of lower performance portfolios. The main characteristics found for these portfolios are: high volatility, low debt, small size, low return on assets and equity, besides of being trade at high prices relative to profit, dividends, and EBITDA. The winner portfolios are characterized by high market risk, positive trend on equity return and low performance relative to the market in the previous month.
\end{abstract}

Keywords: fundamental analysis; portfolios; market efficiency; Bovespa

Received in 05/16/2008; revised in 10/19/2008; accept in 04/12/2008.

Corresponding authors:

${ }^{\dagger}$ Analista Econômico

Endereço: Rua Guarará, 511, apt.

1506, Jardins, São Paulo - SP-

Brazi - CEP:01425-001.

e-mail:luciano_rostagno@yahoo.com.br

Telefone: (11) 8557-1782

\footnotetext{
${ }^{¥}$ Professora Assistente da UNISINOS Endereço: Rua Leblon, no.169, cs. 106, Bairro Ipanema, Porto Alegre - RS - Brazil

CEP 91760-510

e-mail:ksoares@unisinos.br Telefone: (51) 3209-9130
}

\author{
${ }^{¥}$ Professor Adjunto do Programa de \\ Pós-Graduação em Ciências \\ Contábeis da Universidade do Vale \\ do Rio dos Sinos - UNISINOS. \\ Endereço: Rua Leblon, no.169, cs. \\ 106, Bairro Ipanema, Porto Alegre \\ - RS-Brazil - CEP 91760-510. \\ e-mail:rosoares@unisinos.br \\ Telefone: (51) 3209-9130
}

Editor's note: This paper was accepted by Alexsandro Broedel Lopes. 


\section{INTRODUCTION}

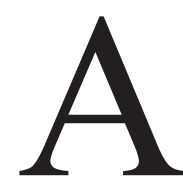

ccording to Kothari (2000), world literature on connections between the subjects Capital Market and Accounting Statements is growing fast in the last decades, notoriously in the academic articles of the accounting and finances areas. Such literature has different focuses, including the fundamentalist analysis and assessment, as well as the market efficacy tests. Despite this global trend, according to Riccio, Carastan and Sakata (2000), within the period between 1962 and 1999, researches relating these subjects in Brazil corresponded to only $1 \%$ out of the total researches in the accounting area, demonstrating that the matter has great potential to the academic investigation in the country.

The main focus of the fundamentalist analysis, still according to Kothari (2000), is on the assessment of bonds, aiming at identifying assets misevaluated. The same author mentions the Financial Accounting Standard Board (FASB) conceptual framework, where appears that the financial statements should help "in assessing the amount, timing and uncertainties as to future cash flows". This kind of analysis comprises, then, the use of information on current and past financial statements, together with macroeconomic and sector data, in order to search to the company's intrinsic value. The difference between the share intrinsic value and its market value would be, therefore, an indicator of the extraordinary return arising from the investment in that bond.

This article uses fundamentalist variables ${ }^{1}$ in order to identify, in average, the profile of the companies said to be "winners", i.e., those presenting the greatest return, and of those shares so-called "losers", as they present the lowest return. In order to do so, monthly portfolios of winners and losers were formed, with the shares traded at Bovespa within the period between January 1995 and December 2002. The analysis made had a descriptive character, aiming at evidencing the portfolios profile in accordance with five variables group, suggested by Haugen and Baker (1996.)

The article was structured as follows: first, the discussion of aspects about the market efficacy forms and its connection with the theoretical and empirical on assets evaluation. Later, empirical studies involving market efficacy and fundamentalist analysis are presented. In sequence, works regarding the subject are approached, undertaken in the Brazilian market. Methodological aspects used in this study are described then. Finally, the empirical data are presented and analyzed, and the final considerations are made.

\section{MARKET EFFICACY AND THEORIES ON EVALUATION}

Controversy existing involving market efficacy raises distinct theories on how to evaluate assets, as well as the possibility or not of previewing shares return. Different opinions on the forms of market efficacy lead, thus, to theoretical and empirical theories diverging on bonds evaluation.

Fama (1970) describes three kinds of market efficacy: week - where the shares current price reflects all its value history, i.e., the whole information contained in the prices passed is entirely incorporated to the current prices; semi-strong - where the share price incorporates instantaneously every new public information available, impeding investors to reach greater profits trying to find assets misevaluated, which would have been done only through the use

\footnotetext{
${ }^{1}$ The variables used in this work are, in great part, related to the fundamentalist analysis. However, there is a group composed of six variables, related to the technical analysis. By convenience in this text, the set of variables dealt will be referred as fundamentalist. BBR, Braz. Bus. Rev. (Eng. ed., Online),

Vitória, v. 5, n. 3, Art. 7, p. 258 - 274, sep.-dec. 2008

www.bbronline.com.br
} 
of privileged information and; strong - where all information, including the confidential one, are reflected on the assets current price, not allowing thus that the use of privileged information by an investor promotes extraordinary returns. It is important to mention that the semi-strong kind comprises also the week kind of efficacy, and the strong form comprises both of them.

As to the theoretical and empirical theories involving assets evaluation and the possibility of obtaining abnormal returns, one can mention the graphic analysis, based on past prices and volumes negotiated; the fundamentalist analysis, based on rates composed by elements of the companies financial statements; and the theoretical economic models, such as the Capital Asset Pricing Model (CAPM).

Each theoretical or empirical current aiming at evaluating shares or getting extraordinary earnings are implicitly under a kind of marker efficacy. The graphic analysis empirical current presupposes inefficient markets, i.e., not even the information on past prices would be incorporated to the shares value. This makes possible the search, through trend analysis on prices, for extraordinary earnings opportunities.

The line based on the fundamentalist analysis presupposes that there is no market efficacy in the semi-strong kind, as in case the market prices reflect the public information on the companies, there will be no opportunities for abnormal earnings based on the information from financial statements.

Finally, market efficacy in its strong kind is a theoretical pillar to the price models developed by financial economists, such as CAPM.

Presupposes on the kind of market efficacy are, thus, directly connected to the theoretical or empirical models on shares prices, i.e., the adherence to one or the other current regarding the evaluation depends on the kind of efficacy or inefficacy shown by the market.

\subsection{Empirical studies on market efficacy and fundamentalist analysis}

Given the connection between the market efficacy kinds and the theoretical and empirical currents on assets evaluation, it is important to search for evidences on the markets efficacy degree. But, on the other hand, given the efficacy premises required to the use of evaluation models, the tests of these models provide now also evidences on the market efficacy kinds.

A study line that is using fundamentalist theories to assembly portfolios and investment strategies is that one aiming to segregate value and growth shares. A seminal work on this matter is of Fama and French (1992), who studied the shares of non-financial companies traded at three stock exchanges in the United States within the period between 1963 and 1990. In the study, the authors ordered, periodically the shares in relation to the dimensions patrimonial value by share/share unit price (VPA/P) and profit/price of share $(\mathrm{L} / \mathrm{P})$, forming 10 portfolios, where the first of them had the shares with greatest value of the dimensions used to order (value shares) and the portfolio of number 10, those of the lowest amount for the same dimensions (growth shares). The purpose was to follow the performance of these 10 portfolios, compare the differences on the returns reached by the extreme values portfolios (numbers 1 and 10) and check if the dimensions used for the formation of the shares portfolios presented a relation with their future returns and risk. The results pointed that the value shares proportionate annual average returns superior to those of growth, besides a lower beta. Among the value shares, the greatest performance was observed to the shares of greatest $\mathrm{VPA} / \mathrm{P}$ ratio.

Capaul, Rowley and Sharpe (1993) made a similar study involving six European countries and Japan. The authors have confirmed the results obtained by Fama and French 
(1992) in all countries.

On the other hand, Lakonishok, Shleifer and Vishny (1994) tried to evidence the influence of other measures, besides the ratio VPA/P, also characterizing value shares, in shares return. The selection of portfolios to the study was made, then, adding the variables cash flow/price and average rate of sales growth, besides the indicators studied by Fama and French (1992). Portfolios were kept constant for the period of five years. The results demonstrate that value shares selected from the variables added have also presented superior returns in respect to growth shares. The performance among the many portfolios of the value shares, however, was approximately the same for the indicators used.

In an attempt to discard standards characterizing the prevision models, such as the requirement of rational economic behavior and market efficacy, Haugen and Baker (1996) have developed a model, based on payoffs regarding the characteristics of their own actions (factors). Such model was called by the authors as Model of Expected Return Factor. To estimate monthly payoffs in the period, factors related to shares return risk, liquidity, reduction, profitability and history were employed. Through multiple regressions, payoffs associated to many factors (average of regression coefficient) and later ordination of the factors according to the statistic safety (absolute value of the averages statistic $t$ ) of each factor were determined. Out of the results 12 factors were extracted as they were considered as important to determine the return expected from the shares. Surprisingly, no risk factor was presented in the most important set. This means that no one of the beta coefficients, related to the market or APT, had significant $t$ values.

The authors have also used the same factors model to the prognosis of the future relative return of shares in five countries. ${ }^{2}$ The result for all countries, surprisingly, has demonstrated that the lower risk shares have presented the greatest return rate expected and held (negative payoffs for the debt, monthly return variability of a share and variability in shares return not explained by the market movement). Reversion standards at short term (negative payoffs on the returns from one to three months) and long terms (negative payoffs on the return of five years) on shares returns were noticed, as well as medium term impulse (positive payoffs for the 12 months return); irreversibility standards for the reduction (positive payoffs in the patrimonial value per share/price, cash flow/price, income/price and sales/price ratios) and of profitability (positive payoffs in the return on the estate). The study highlight also the fact of the most important determiners of the expected shares return show themselves as uniform among the countries inserted in the test. The explanation for such, according to the authors, lies on the common aspects of the human behavior in the many markets. Investors tend to overestimate most recent information from the inaccurate idea of the true duration of the short term, and that they are subject to the same agency problems.

\subsection{Brazilian Market}

The studies on fundamentalist analysis in the Brazilian market follow, in general, the approaches made in American studies, focusing, mainly, on the indicators differentiating value shares from the growth ones.

Torres, Bonomo and Fernandes (2002) tried to test the hypothesis of the random walk in the Brazilian market. Using daily, weekly and monthly returns from individual and portfolio grouped shares ${ }^{3}$, the study aimed at assessing investment strategies of short, medium and long term. The tests made on the hypothesis of the returns being not correlated and independent have demonstrated, for daily and weekly returns, a persistence of the returns,

\footnotetext{
${ }^{2}$ The countries inserted in the test were: United States, France, Germany, Japan and Great Britain.

${ }^{3}$ This study uses portfolios equally weighted and portfolios weighted by value.

BBR, Braz. Bus. Rev. (Eng. ed., Online),

Vitória, v. 5, n. 3, Art. 7, p. 258 - 274, sep.- dec. 2008

www.bbronline.com. $b r$
} 
which led to the rejection of the random path hypothesis. The seasonal effect of the returns on Mondays was noticed, showing to be lower than the other days of the week. However, there was a weaker rejection of this hypothesis in the post-real period and, also, only for shorter time horizons, taking the authors to the conclusion that the Brazilian market is turning into more efficient.

In turn, Brito and Manazes (1981, apud Torres, Bonomo and Fernandes, 2002, p. 195) sought to check the possibility of anticipating future assets returns using only past or historical returns, the so-called technical or graphical analysis. In this study, the authors aimed at pointing evidences of previewing the daily returns in the Brazilian shares market through the rejection of the hypothesis that the market would be efficient in the week kind. Using data involving the period between 1973 and 1980, the study has found results statistically significant, denoting reversion standards to the average of the returns in a considerable share of the sample used. Therefore, shares with good performance in the past, in average, would have a week performance in subsequent periods and vice-versa. Torres, Bonomo and Fernandes (2002), however, have stressed that the results found in this study can be consequence of a low liquidity of the shares incorporated to the sample.

Costa Jr. and Neves (2000) sought to check the existence of other variables - market value, price/profit ratio and patrimonial share value/share price - besides beta, as explanatory factors to the shares returns. The period of study was from January/86 to February/96 and the sample was composed by 117 shares traded at Bovespa. Ordered portfolios were formed through the $\mathrm{P} / \mathrm{L}$, market value, VPA/P rates, and the portfolios were rebalanced at each year. The study has pointed a negative relation between the portfolios average profitability and the variables $\mathrm{P} / \mathrm{L}$ ratio and market value. As to VPA/P, the relation found was positive. Finally, the authors have concluded that, despite of the contribution of such variables to the explanation of shares return, the beta coefficient was the one presenting the best explanation power.

With the purpose of testing beta coefficient capacity as to the explanation of shares returns in Brazil, Mellone Jr. (1999) has initially tested the existence of a positive linear relation between beta and shares return. After the verification of such ratio, a multiple regression was held to check the significance of such relation, using as factors the size (net equity), financial leveraging, profit/price rate and patrimonial amount on the market value. The study has comprised the period between the months of 01/94 and 08/98, with a sample formed by 233 shares negotiated in the Stock Exchange of São Paulo. The results have pointed that, regarding CAPM, there is no linear relation between shares returns and their respective betas and, as to the multi-factors model, the variables profit/price and patrimonial value on the market value would be relevant in the explanation of shares return, in accordance with French and Fama (1992) results. The other variables studied representing the size and financial leveraging are not relevant to determine the returns.

Rodrigues (2000) sought to check on the existence of the value and size effects as determinants to the shares risk. The sample was formed by 180 shares traded at Bovespa in the period from $06 / 1991$ to $05 / 1999$. The author has also built shares portfolios based on the indicator market value/patrimonial value and also based only on the market value, the first and last quartile being the cut point to the portfolios. Portfolios were rebalanced year by year. Thus, investment strategies based on value, growth shares and those of greater and lower market value companies were examined. As result, the author points out the superiority of the strategies based on value shares in relation to those of growth. But the first ones have presented a higher risk. In turn, the size effect was favorable to the shares of greater market value companies. 
A test of the existence of golden opportunity, a term used by Haugen (2000) in the Brazilian market was undertaken by Ramos, Picanço and Costa Jr. (2000), who reapplied the study made by Haugen (1995), which has found evidences against to the market efficacy theory. For such, the authors used data from the shares of the companies listed in Bovespa from 1989 to 1994, excluding the financial companies. Ordered portfolios were constructed based on the variable VPA/P, classifying the $20 \%$ of the shares with greatest ratio as value shares and those of lowest ratio as growth shares. The results have confirmed the evidences of the existence of the golden opportunity, once that the value shares have presented greatest return and lowest risk. However, the statistic significance of the results was low.

As well as Ramos, Picanço and Costa Jr. (2000), Braga and Leal (2002) sought for new evidences of the superiority of the investment strategy in value shares. In this study, besides the variable accounting value/market value, the factor size was used to select the portfolios in the period between June 1991 and June 1998. The results have not confirmed the size effect found by Costa Jr. and Neves (2000), but they have confirmed a positive relation between the variable accounting value/market value and the return offered. In risk analysis, however, the value portfolios presented a variation higher than those of growth, in addition to a greater Sharpe rate (significant at 10\%).

With greatest statistic significances in the results, the Rostagno, Soares and Soares study (2003) pointed to an inversion of the risk-return ratio (in dollars) in the Brazilian shares market. Four fundamentalist variables were tested in this study for the classification of shares: share accounting value/market value, profit/price, dividends/price and sales/price. For all variables, the value shares overcame, in average and accrued profitability, the growth portfolios, in addition to present lower average beta to the test period (June 1995 to June 2001). The stand out, however, was with the portfolio ordered as from the ratio profit/price where the significances have reached the level of $1 \%$ to the differences of averages of the returns and betas.

Halfeld and Procianoy (2000) have also made use of fundamentalist variables to check on the inversion of the risk-return relation in Brazil. The authors have confirmed the presence of anomalies in the Brazilian market and stressed that these have presented themselves as more acute in the period prior to the crisis in Mexico. According to the authors, Mexico crisis would have altered investor's behavior, making Brazil to be the preferential market for investments in Latin America, and orienting the focus of such investments in Brazilian companies renowned and of large size. Moreover, Telebras privatization process is mentioned as having caused a concentration of investment in these roles, reducing the premiums in investments on value shares.

The results found by Halfeld, Silva and Sato (2001), who made similar study in other countries in Latin America are alike those of Halfeld and Procianoy (2000). The countries involved in the study, extended from September 1993 to December 1998, were: Brazil, Argentina, Chile, Colombia, Mexico, Peru and Venezuela. As results, the value strategies have shown to be superior, compared to the growth ones, to shares with high ROE, in all countries studied, except for Argentina, where this fact would be significant only if the statistic significance level would be increased to $6.5 \%$.

As exposed, the Brazilian studies involving fundamentalist variables seek to assess statistically the performance of the portfolios constructed based on such variables. This work, in turn, adopts a distinct analysis line, once that it forms portfolios based on the return reached in the period, and tries to test fundamentalist and technical variables capable of differencing such portfolios. 


\section{STUDY DESCRIPTION}

The sample was composed by the Brazilian public limited companies, with shares traded at the Stock Exchange of São Paulo, in the period between January 1995 and December 2002. The tests period was chosen due to the high inflation indexes in force before the Real plan (June 1994). Thus, the profile of the portfolio of shares considered as winners (greatest return), and losers (lowest return), before a time interval where it was not necessary to deflation the indexes composing the factors. According to Leal and Rêgo (2000), the high inflation rates present before the Real plan distorted the prices of the assets traded in the Brazilian capital market, what would compromise the study. To the companies accomplishing the criteria of the negotiation period, but presenting more than a series of shares, only the greater liquidity series was included. The scope of this research has excluded the financial and insurance institutions, once that, by definition, these companies operate strictly leveraged. Therefore, the sample was composed by 70 shares, selected as from the database Economática

\subsection{Methodological Procedures}

The first step of this work has consisted on the classification of shares according to the return obtained in each month of the period selected for the analysis. The return rates were calculated presupposing discrete capitalization, representing, thus, the income nearest to the actual offered by the assets. Mathematically, the return calculation has followed the following equation:

$$
R_{j, t}=\frac{P-P}{P_{j, t-1}^{j, t-1}}
$$

Where,

$R_{j, t}$ is the total return of the share $j$, in month $t$;

$P_{j, t}$ is the closure quotation to the share $j$, in month $t$, adjusted to dividends and other provisions occurred in the period; and

$P_{j, t-1}$ is the closure quotation to the share $j$, in month $t-1$.

The sample was, then, divided in quintiles according to the performance, in crescent order of returns, what resulted in a total of 14 shares for each monthly portfolio. Thus, the first quintile represents the group of shares with the lowest performance in the month, and the last quintile comprises the best performance companies. According to Ceretta and Costa Jr. (2000), this number ensures the elimination of great part of the diversifiable risk of the portfolio in the Brazilian market.

The next stage involved the calculation of the arithmetic average, in the month, of each fundamentalist variable for each portfolio (quintile) formed. It is important to mention that the average did not suffer any kind of weighing and, therefore, each share has contributed with the same installment for the composition of the portfolio.

The selection of the fundamentalist variables used in this study is based on the Haugen and Baker (1996) work, and represents some of the characteristics of the companies that could induce differentials to the returns expected from the shares. These can be classified in five groups of factors: risk, liquidity, reduction, profitability and technical factors.

It is worth it to mention that the reduction measures were taken in the month prior to the calculation of the return, as they suffer direct influence from the shares prices. The intention is to check if these measures can be used, anticipatedly, to capture the greatest and lowest performance shares in the Brazilian market. The profitability measures were also computed in a different way. As they are available only by quarters, they were computed only 
in the months they were available to calculation. Therefore, only the returns corresponding to the months when these variables were present were taken for classification.

Table 1 presents the description of the variables used, as well as the way they were obtained. As well as the sample, all variables were obtained as from the database Economática.

Once the average of the portfolios fundamentalist variable for the whole period, the next step was to check if the different performance portfolios really present distinct profiles through a hypothesis test. For such, the test $t$ of average difference to aligned samples of the variables among the quintiles was held. The hypothesis tested for each fundamentalist variable was:

Null hypothesis $(\mathrm{H} 0)$ - the averages of the fundamentalist variables of the different shares performance groups are not statistically different and, therefore, there is no aspect regarding the companies profile that characterizes the relative performance of the portfolios.

Alternative hypothesis (H1) - the averages of the fundamentalist variables of the different shares performance groups are statistically different and, therefore, there are aspects regarding the companies profile that characterize the relative performance of the portfolios.

As a result of this test, there was a simetric matrix $(5 \times 5)$ for each variable inserted in this study. Each matrix has comprised all the possible average difference test combinations among the performance portfolios. The purpose of such procedure is to raise the aspects characterizing the profile of the portfolios of the different incomes in the Brazilian capital market. 


\begin{tabular}{|c|c|c|}
\hline Factor & Proxy & Description \\
\hline \multirow{8}{*}{$\vec{z}$} & Market beta & Regression of the last 60 months of excess in monthly returns \\
\hline & Volat. of total return & Share volatility in the last 60 months \\
\hline & Residual variation & Standard error of the reg. line in the last 60 months (risk not market-rel.) \\
\hline & Income risk & Standard error in the reg. line of inc. by share in the previous year \\
\hline & Debiting coefficient & Curr. Liability + long term $\div$ share net equity \\
\hline & Debt trend & Inclination of the regres. line of the debt coefic. of the last 5 years \\
\hline & Variability - incomes & Standard deviation of the profit by share in the last five years. \\
\hline & Variability - dividends & Standard deviation of the dividends by share in the last five years \\
\hline \multirow{4}{*}{ 怘 } & Market capitalization & Share quotation in the market by the number of shares circulating \\
\hline & Market price by share & Share quotation in the market. \\
\hline & \begin{tabular}{|l|l|} 
Volume of market \\
trade/capitalization
\end{tabular} & $\begin{array}{l}\text { Coefficient of the monthly negotiation volume average } \div \text { average of the } \\
\text { market capitalization of the last } 12 \text { months }\end{array}$ \\
\hline & Negoc. vol. trend. & Inclination of the regres. line of the mont. negoc. vol in the last 5 years \\
\hline \multirow{10}{*}{ 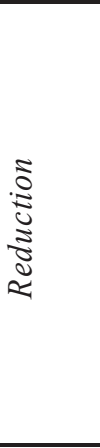 } & VPA/price ratio & Most recent VPA available divided by the current market price \\
\hline & VPA/price trend & Inclin. regress. line of the patrim. value by share $\div$ price last 5 years \\
\hline & Profit/price ratio & Profit available of the 4 most recent quarters $\div$ current market price \\
\hline & Profit/price trend & Incl. regres. line of the profit/price ratio in the last 5 years \\
\hline & Dividend/price ratio & Annual dividend available $\div$ current market price \\
\hline & Div./price ratio trend & Incl. regres. line of the dividends/price ratio for the last 5 years \\
\hline & EBITDA/price ratio & Own operational profit + deprec. and amort. $\div$ current market price \\
\hline & EBITDA/price ratio trend & Inc. reg. line of the EBITDA/price ratio of the last 5 years \\
\hline & Sales/price ratio & Op. liquid revenue by share $\div$ current market price \\
\hline & Sales/price ratio trend & Inc. reg. line sales/price ratio of the last 5 years \\
\hline \multirow{9}{*}{ 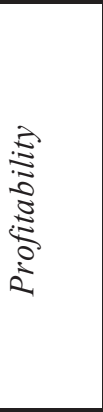 } & Net profit margin & Net profit $\div$ operational net revenue. \\
\hline & Net profit marg. Trend & Inc. reg. net profit margin of the last 5 years \\
\hline & Assets working & Operating net revenue $\div$ total assets \\
\hline & Asset working trend & Inc. reg. line asset working of the last 5 years \\
\hline & Return on the assets & Net equity $\div$ total asset \\
\hline & Ret. over the asset trend & Inc. regres. line of the return on the asset of the last 5 years \\
\hline & Return over the NE & Net profit $\div$ net equity \\
\hline & ROE trend & Inc. regres. line of the return over NE of the last 5 years \\
\hline & Profits growth & Evol. inc. by share year by year $\div$ inc. avg. by share in the last 5 years. \\
\hline \multirow{6}{*}{ 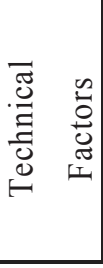 } & Exces. ret - prior month & Difference of return regarding Ibovespa in the prior month \\
\hline & Exces. ret - 2 months pr. & Difference of return regarding Ibovespa in the 2 months prior \\
\hline & Exces. ret - 3 months pr. & Difference of return regarding Ibovespa in the 3 months prior \\
\hline & Exces. ret -6 months pr. & Difference of return regarding Ibovespa in the 6 months prior \\
\hline & Exces. ret - 12 months pr. & Difference of return regarding Ibovespa in the 12 months prior \\
\hline & Exces. ret - 24 months pr. & Difference of return regarding Ibovespa in the 24 months prior \\
\hline
\end{tabular}

Table 1 : Fundamentalist variables used

\section{MAIN RESULTS}

This section presents the results obtained for the five groups of variables tested. It is worth it to mention that only the variables reaching statistic significance at the level of $10 \%$ in the tests applied were reported. The annex 1 contains all the matrixes with the average difference tests results among the quintiles. 


\subsection{Risk measures}

Among the variables representing the group risk, market beta, total return volatility, debting coefficient, debting trend and the variability of income were those showing as relevant to the differenciation among the quintiles.

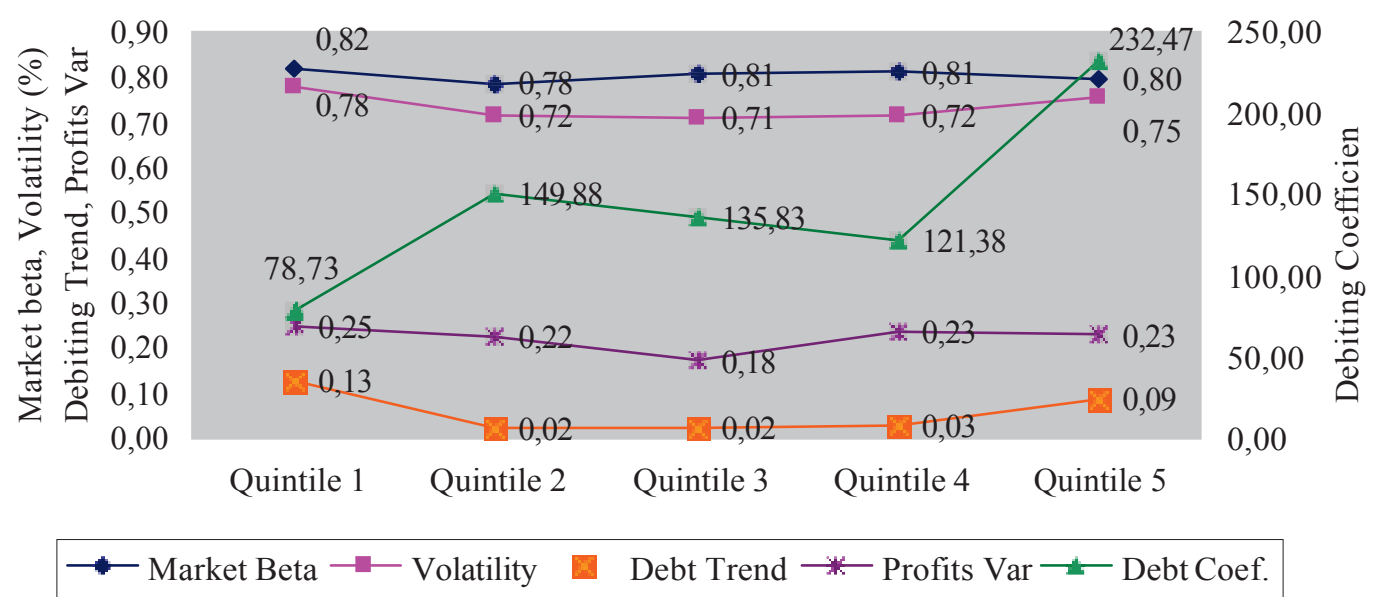

Figure 1: Quintile risk characteristics.

As verified in Figure 1, there was an inversion of market beta between the quintile of the loser shares and that of the winner ones, i.e. the shares reaching greater return were those presenting, in average, the lowest systematic risk. Test $t$, in this case, was significant at the level of $10 \%$. As to the intermediate portfolios, these did not differentiate themselves in a regular way to the extremes' portfolios.

Analyzing the volatility of the total return, the quintile 1 was again that presenting the lowest risk (0.78). It can be observed also that the winner quintile presented an average volatility $(0.75)$ higher than the intermediate quintiles $(2,3$ and 4$)$. In this case the extreme quintiles are different of all intermediate quintiles, reaching statistic significance of $1 \%$ to all tests made. Intermediate portfolios, however, did not differentiate among themselves.

To the debiting coefficient, the extreme quintiles results were according to the financial theory, as the greatest return portfolios have presented greater risk and vice-versa. This, however, was not observed to the intermediate portfolios. As to the statistic significance of the averages difference test between the quintiles 1 and 5 , this has reached the level of $5 \%$.

But the debiting trend showed itself greater for the greatest and lowest incomes in the period ( 0.13 and 0.09 , respectively). The result found for this variable is interesting, once that such portfolios are different from the others, but not among themselves. This indicates that portfolios with greater trend to debt can generate greater profits or losses to their investors. As to the intermediate portfolios $(2,3$ and 4$)$, there was a greater conservativeness in the debt trend, not having, however, a clear distinction among them.

Finally, the lower profit variability portfolios $(0.18)$ were those composing the third quintile, as they have differentiated themselves from all the others with significance at $5 \%$. 


\subsection{Liquidity measures}

As to the aspect liquidity, the indicators demonstrating as differentiators from the performance quintiles were: market capitalization and market price by share ${ }^{4}$. Different from the expected, the variables negotiation volume/market capitalization and trend of negotiation volume were not capable of detecting inequalities in the quintiles profile.

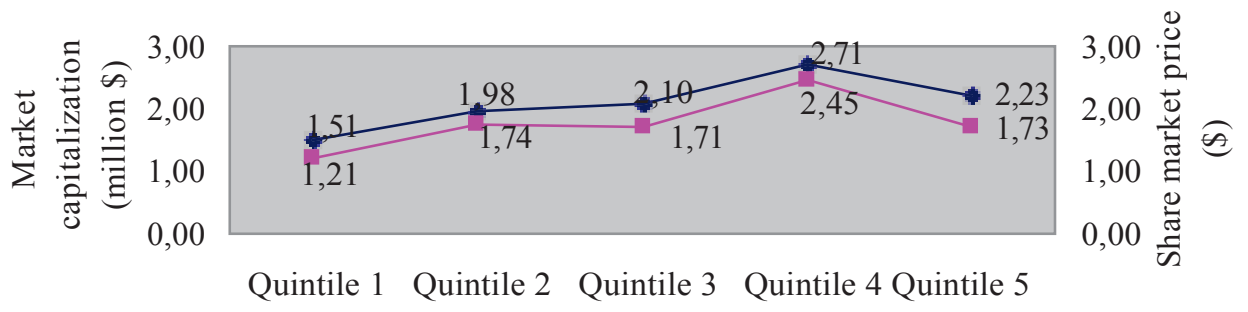

$$
\rightarrow \text { Mar. Cap. } \rightarrow-\text { Mar. Price }
$$

Figure 2: Quintiles liquidity characteristics.

Observing figure 2, it is evidenced that the lowest performance companies were those of smaller size and lowest market price by share. In turn, the companies of greater size and market unit value were in the fourth quintile, i.e., they have reached the second place as to the returns offered. The statistic significances of the tests applied between the averages found to the quintiles 1 and 4 and the others were all of the order of $5 \%$.

\subsection{Reduction Measures}

The reduction measures aim at assess the relation between accounting data and the market value of the company share. Out of the variables studied, the following measures can be highlighted as capable of evidencing differentials in shares prices: patrimonial value by share/price trend, profit/price ratio, profit/price trend, dividends/price, dividends/price trend, EBITDA/P relation and sales/price relation. The results obtained for such variables are shown in Figure 3.

First, it is important to mention that the measure patrimonial value/price, very used in studies involving fundamentalist variables, was not relevant as indicator of shares performance difference in the Brazilian market. However, the measure of its trend was capable of differentiating the first quintile from the others (significant to the level of 5\%), this being that presenting the most negative inclination of the regression line (-0.0008). The shares with lowest earnings in the market were noticed to be those with the projection of greatest fall in the relation patrimonial value/price.

In the analysis of the index profit/price one may highlight that the shares with lowest ratio for such variable $(-48.57 \%)$ have result in a lowest return in the subsequent month, an evidence obtained with significance at the level of $1 \%$. For the quintile 5 (companies with greatest performance) the result observed, despite of being the second most negative in the ratio studied $(-20.82 \%)$, did not allowed to take further conclusions, once that this has not differentiated itself from the quintile 2. For the trend of this same measure, the actions with great propensity of growth in the index profit/price were those resulting in the greatest earnings or losses to the shareholders. Quintile 5 has differentiated itself from the intermediate

\footnotetext{
${ }^{4}$ The idea around these variables lays on the fact that, in the Brazilian market, in general, the large size company shares are these presenting greater liquidity and that shares with lower unit value would allow a greater number of deals.
}

BBR, Braz. Bus. Rev. (Eng. ed., Online),

Vitória, v. 5, n. 3, Art. 7, p. 258 - 274, sep.- dec. 2008

www.bbronline.com.br 
quintiles (2,3 and 4), but not from the first quintile. The first quintile has also not shown itself different from quintile 4.

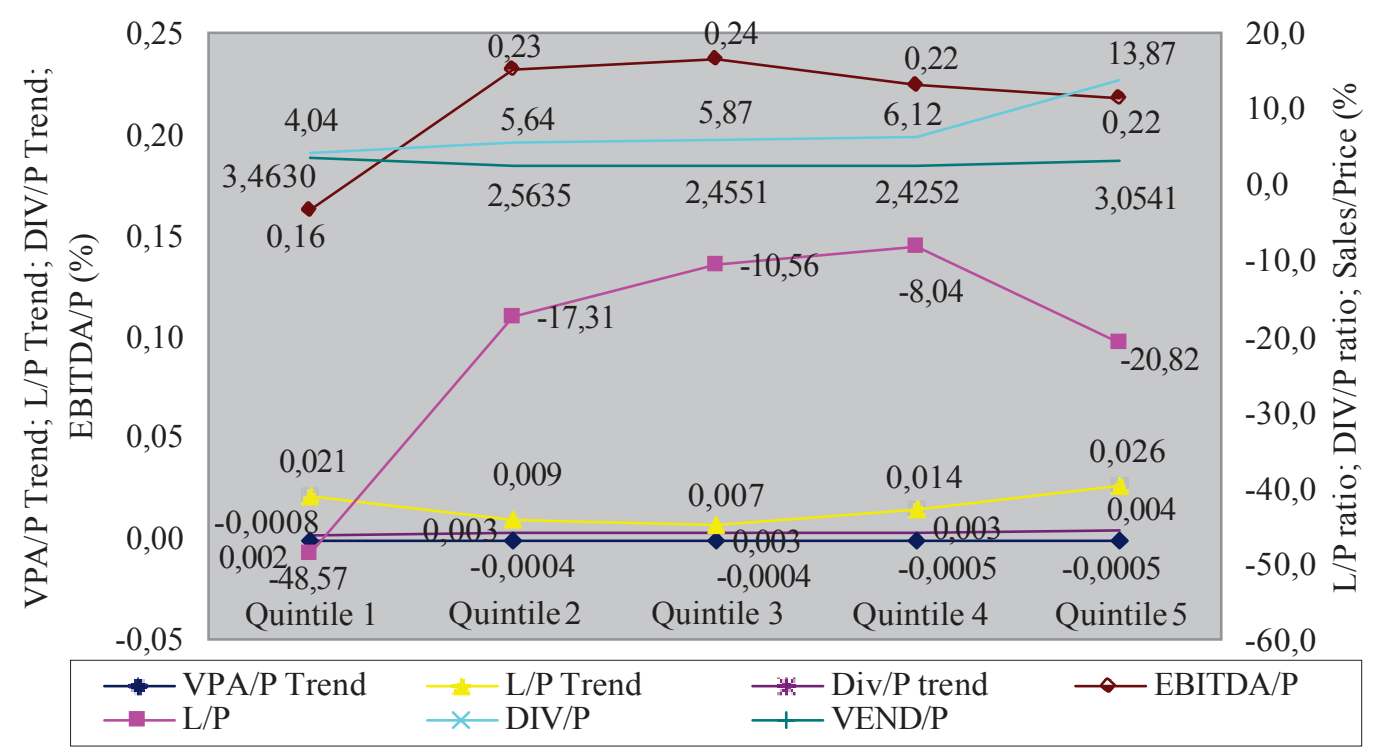

Figure 3: Quintiles reduction characteristics.

It is important to mention an aspect for the following reduction variables: dividends/price relation, dividends/price trend and EBITDA/price. The lowest performance portfolios stood out among the others as they have smaller amounts of these measures $(4.04 \%$; $0.00179 ; 0.162 \%)$. The averages difference tests between the quintile 1 and the others have reached significances at $10 \%$. As to the other portfolios, there was no evidence of distinction among them.

Finally, the ratio sales/price has shown that the quintiles 1 and 5 (losers and winners, respectively), are different from the others as they have a greater value of this variable. However, these portfolios are not different among themselves, for the significance interval set out in the study $(10 \%)^{5}$

\subsection{Profitability Measures}

The results for the profitability measures - return over the assets, return over the net equity and trend of return over the net equity - can be viewed in Figure 4. The study of these measures aims at relating the internal return of the company with its return in the capital market.

As the result found for the significant reduction measures, the quintile 1 portfolios were distinguished from the others, being those verifying lowest returns over the asset and net equity $(-7.65 \%$ and $-20.4 \%$, respectively). These results were proven to the level of $5 \%$ of significance.

On the other hand, when the variable return trend over the net equity was analyzed, quintile 5 has stood out among the others (5\% of significance) presenting a greater value in the growth perspective (0.00798).

\footnotetext{
${ }^{5}$ As it can be verified in annex 1, the test of difference of averages between quintile 1 and 5 was significant to $11 \%$, therefore, very close to the cut point adopted in this study.
} 


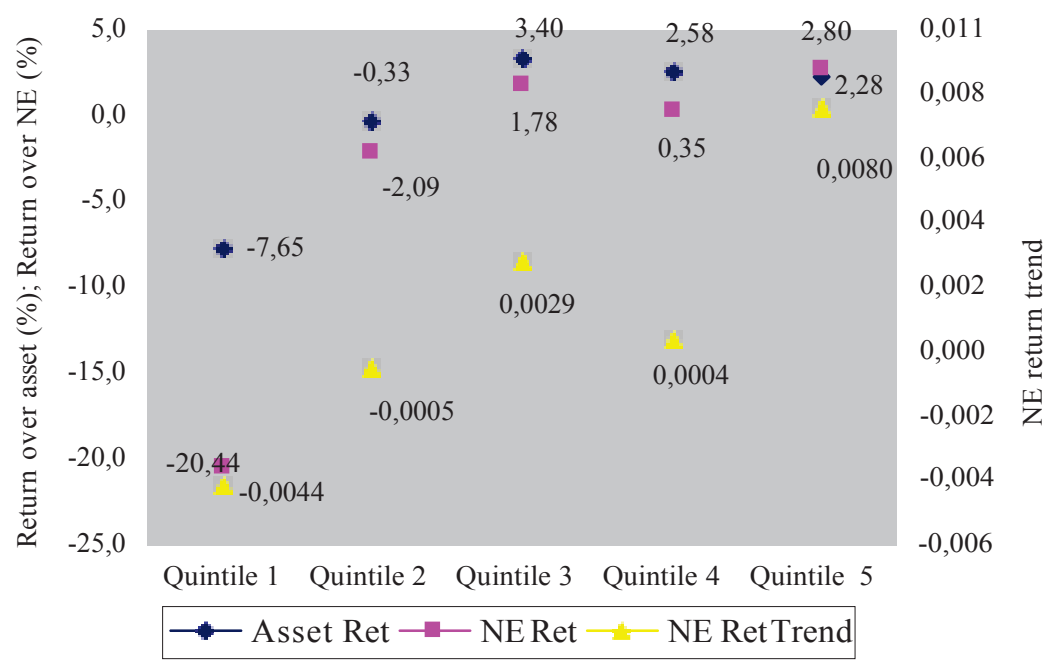

Figure 4: Quintiles profitability characteristics.

\subsection{Technical Factors}

The technical factors aim at detecting evidences of assets prices behavior trends throughout time. Thus, these ratios, through different measurements intervals, try to capture reversion or continuity moments of shares return. In this group of variables, the indicators return excess of 1 month and return excess of 6 months were those best performing the role of mapping the behavior of the shares inserted in this study.

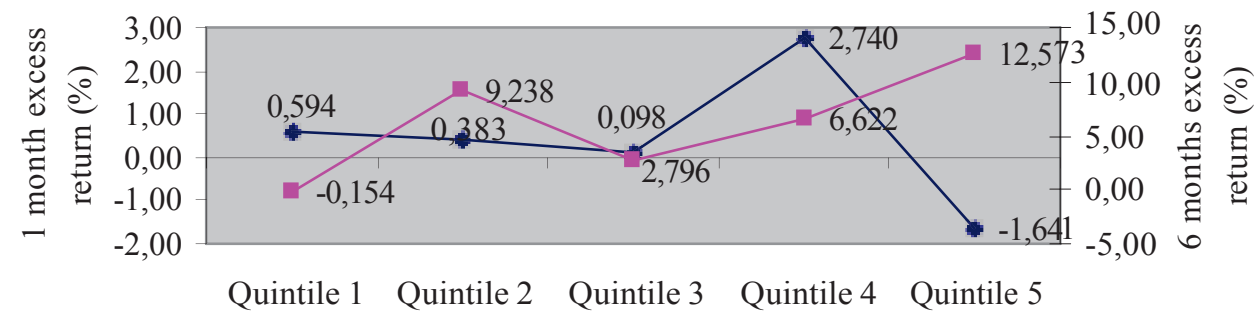

$$
\longrightarrow \bullet \operatorname{Ex} 1 \mathrm{~m} \longrightarrow-\operatorname{Ex} 6 \mathrm{~m}
$$

Figure 5: Quintiles technical factors characteristics.

According to Figure 5, a reversion trend of very short term (1 month interval) can be noticed for the winning companies. These were the only presenting a negative average ($1.64 \%$ ) for the measure of excess if return of one month, besides having differentiated from the other portfolios (significant to $10 \%$ ), except for the quintile 4, which significance interval was of $10.21 \%$.

For the 6 months interval (short term) a continuity effect of the returns was observed. The shares of income inferior to Ibovespa in the six months prior kept a low performance in the following month (quintile 1). The difference in the averaged between quintile 1 and the others was significant to the level of $10 \%$.

\subsection{Summary of the results}

Table 2 presents, in summary, the results of the variables presenting statistic significance in the definition of the loser, intermediate and winner portfolios profile. 


\begin{tabular}{|c|l|l|}
\hline Portfolios & \multicolumn{1}{|c|}{ Proxy } & \multicolumn{1}{c|}{ Result } \\
\hline \multirow{5}{*}{ Losers } & Total retiurn volatility & High value \\
\cline { 2 - 3 } & Debiting coefficient & Low value \\
\cline { 2 - 3 } & Market capitalization & Low value \\
\cline { 2 - 3 } & Share market price & Low value \\
\cline { 2 - 3 } & VPA/P Trend & High negative trend \\
\cline { 2 - 3 } & L/P ratio & Low value \\
\cline { 2 - 3 } & DIV/P ratio & Low value \\
\cline { 2 - 3 } & DIV/P Trend & High positive trend \\
\cline { 2 - 3 } & EBITDA/P & Low value \\
\cline { 2 - 3 } & Return over the assets & Low value \\
\cline { 2 - 3 } & Return over the NE & Low value \\
\cline { 2 - 3 } & Exc. ret 6 prior months & Low value \\
\hline \multirow{5}{*}{ Intermediate } & Volatility of the total return & Low value \\
\cline { 2 - 3 } & Debt trend & Low positive trend \\
\cline { 2 - 3 } & Sales/price index & Low value \\
\hline \multirow{5}{*}{ Winners } & Total return volatility & High value \\
\cline { 2 - 3 } & Return over NE trend & Low value \\
\cline { 2 - 3 } & Prior month ret. exc. & igh positive trend \\
\hline
\end{tabular}

Table 2: Summary to the quintiles characteristics results

\section{FINAL CONSIDERATIONS}

The purpose of this study was of outlining the profile of portfolios with different performances, based on fundamentalist and technical variables, for shares traded at Bovespa in the period later the Real Plan. A total of 37 representative variables were considered out of the following factors groups: risk, liquidity, reduction, profitability and technical factors.

As from the selection of portfolios according to the performance reached by the shares in the market and of the statistic tests applied on the variables considered, the profile of each group could be outlined: loser portfolios (quintile 1), intermediate portfolios (quintiles 2,3 and 4) and winner portfolios (quintile 5). It is important to stress that the analysis presented herein are related to the portfolios and not to the shares individually.

In general, loser portfolios were characterized as having high total market risk (volatility), low internal risk (debiting), smaller size, lower market price, and they are little profitable in relation to their asset and net equity and they were traded in the market at high prices related to the dimensions profit, dividends and EBITDA. In relation to the price history, they had a performance inferior to the market in the prior six months. Furthermore, these portfolios present shares with a projection of greater low of the net equity/price relation. On the other hand, the trend of the dividends/price relation with raising perspectives is like a paradox to the trend prior described.

The profile raised to the intermediate income portfolios has demonstrated that these are of low total market risk (volatility) and, also, they tend to increase its debiting a little. As to the dimension of the price level of the shares composing these portfolios, a low sales/price relation was observed. A possible explanation for this would be the high market value by share of the companies composing the quintile 4 , what could have changed the averages of the intermediate portfolios.

On the other hand, the winner portfolios are characterized as having high total market risk (volatility), projection of increase in the return over the net equity and a low income related to the market in the prior month. This last characteristic observed suggests a reversion of the returns to the average at short term. Thus, shares portfolios having low returns in one month would produce high returns in the following month. 
It is important to mention further that this study can present problems with survival means. The reason for such is that the sample was composed from the database Economática, which excludes the companies when these cease to be traded at the stock exchange.

As suggestion to future events, the importance of testing alternative models of evaluation, capable of incorporating the differences of the shares with distinct performances, in diverse conditions of market efficacy, can be raised. Moreover, it would be interesting to check if the paradox raised in relation to the variables of Trend VPA/P and Trend DIV/P, of the loser portfolios, could be explained by the raising in the distribution of dividends with the intention of improving the company market value, even against the conservation of their estate.

\section{REFERENCES}

Braga, C. A., Leal, R. Ações de Valor e de Crescimento nos Anos 90. IN: Finanças Aplicadas ao Brasil - Rio de Janeiro : Editora FGV, p.235-248, 2002.

Capaul, C., Rowley, I., Sharpe, W. International Value and Growth Stock Returns, Financial Analysts Journal, 49, 27-36, 1993.

Ceretta, P. S., Costa Jr., N. C. A. da. Quantas Ações Tornam um Portfólio Diversificado no Mercado de Capitais Brasileiro?, IN: Mercado de Capitais - Análise Empírica no Brasil São Paulo : Atlas, 2000.

Costa Jr., N., Neves, M. Variáveis Fundamentalistas e Retornos das Ações. in Costa JR., N. Leal, R., Lemgruber, E. Mercado de Capitais - Análise Empírica no Brasil. São Paulo: Atlas, 2000.

Fama, E. F. Efficient Capital Markets: a Review of Theory and Empirical Work. Journal of Finance, 25, 383-417, 1970.

Fama, E., French, K. The Cross-section of Expected Stock Returns, Journal of Finance, 47, 427-465, 1992.

Halfeld, M., Procianoy, J. A Ineficiência nos mercados do Brasil e de outros países da América Latina. in Haugen, R. Os Segredos da Bolsa. São Paulo: Pearson, 2000.

Halfeld, M., Silva, L.A., Sato, A. Analise de estilos de investimentos em ações no mercado da América Latina. Revista de administração da USP: volume 36, nº 1, p.57-63, 2001.

Haugen, R. The New Finance: The Case Against Efficient Markets, Prentice Hall, Englewood Cliffs, N. J., 1995.

Haugen, R., Baker, N. L. Commonality in the Determinants of Expected Stocks Returns,

Journal of Financial Economics, 41, 401-439, 1996.

Haugen, R., Os Segredos da Bolsa. São Paulo: Pearson, 2000.

Kothari, S. P.. Capital Markets Research in Accounting. Working Paper MIT, (2000) SSRN. Lakonishok, J., Shleifer, A., Vishny, R. Contrarian Investment, Extrapolation, and Risk, Journal of Finance 49, 1541-1578, 1994.

Leal, R. P. C., Rêgo, R. B. Impacto do Anexo IV no Mercado de Capitais Brasileiro, IN:

Mercado de Capitais - Análise Empírica no Brasil - São Paulo : Atlas, 2000.

Mellone Jr., G. Evidências empíricas da relação cross-section entre retorno e earnigs to price ratio e book to market ratio no mercado de ações no Brasil no período de 1995 a 1998 . Foz do Iguaçu: Anais do XXIII ENANPAD, 1999. 
Ramos, P., Picanço, M., Costa Jr., N. Retornos e Riscos das Value e Growth Stocks no Mercado Brasileiro. in Costa Jr., N. Leal, R., Lemgruber, E. Mercado de Capitais - Análise Empírica no Brasil. São Paulo: Atlas, 2000.

Riccio, E. L., Carastan, J. T., Sakata, M. G. Accounting Research at Brazilian Universities. Melbourne: XXI Asian-Pacific Conference, 2000.

Rodrigues, M. O Efeito Valor, o Efeito Tamanho, e o Modelo Multifatorial: Evidências do Caso Brasileiro. Florianópolis: Anais do XXIV ENANPAD, 2000.

Ross, S. Waterfield, R. , Jaffe, J. Administração Financeira. São Paulo: Atlas, 1995.

Rostagno, L. M., Soares, R. O. , Soares, K. T. C. Value Strategies in the Brazilian Stock Markets. São Paulo: Proceedings of Business Association of Latin American Studies Balas, 2003.

Torres, R., Bonomo, M., Fernandes, C.. A aleatoriedade do passeio na Bovespa: testando a eficiência do mercado acionário brasileiro. In Bonomo, M. Finanças aplicadas ao Brasil. Rio de Janeiro: Editora FGV, 2002. 
Attachment 1: Matrixes of the results of the tests of the differences of the averages among the quintiles

\begin{tabular}{|c|c|c|c|c|c|c|c|c|c|c|c|}
\hline \multicolumn{6}{|c|}{ Market beta } & \multicolumn{6}{|c|}{ VPA/P Trend } \\
\hline & Q2 & Q3 & Q4 & Q5 & AVERAG & & Q2 & Q3 & Q4 & Q5 & AVERAGE \\
\hline Q1 & 0,0018 & 0,1256 & 0,2514 & 0,0678 & \begin{tabular}{|l|l|} 
& 0,8219 \\
\end{tabular} & Q1 & 0,0003 & 0,0004 & 0,0051 & 0,0231 & $-0,0008$ \\
\hline $\mathrm{Q} 2$ & - & 0,0443 & 0,0118 & 0,1814 & 0,7825 & $\mathrm{Q} 2$ & - & 0,4979 & 0,3159 & 0,1487 & $-0,0004$ \\
\hline Q3 & & - & 0,2853 & 0,2616 & 0,8055 & Q3 & & - & 0,3070 & 0,1734 & $-0,0004$ \\
\hline Q4 & & & - & 0,0931 & 0,8124 & Q4 & & & - & 0,2881 & $-0,0005$ \\
\hline Q5 & & & & - & 0,7964 & Q5 & & & & - & $-0,0005$ \\
\hline \multicolumn{6}{|c|}{ Volatility } & \multicolumn{6}{|c|}{ Profit/price ratio } \\
\hline & Q2 & Q3 & $\mathrm{Q} 4$ & Q5 & \multicolumn{2}{|c|}{ AVERAGE } & Q2 & Q3 & Q4 & Q5 & AVERAGE \\
\hline Q1 & $2,1 \mathrm{E}-13$ & $5,9 \mathrm{E}-16$ & $2,4 \mathrm{E}-14$ & $6,9 \mathrm{E}-04$ & $7,8 \mathrm{E}-01$ & Q1 & $8,0 \mathrm{E}-07$ & $2,3 \mathrm{E}-08$ & 4,1E-09 & $2,6 \mathrm{E}-04$ & $-4,9 \mathrm{E}+01$ \\
\hline $\mathrm{Q} 2$ & - & $1,8 \mathrm{E}-01$ & 4,5E-01 & $6,3 \mathrm{E}-06$ & $7,2 \mathrm{E}-01$ & Q2 & - & 0,0636 & 0,0169 & 0,2797 & $-17,3115$ \\
\hline Q3 & & - & $2,1 \mathrm{E}-01$ & $1,3 \mathrm{E}-06$ & $7,1 \mathrm{E}-01$ & Q3 & & - & 0,2808 & 0,0393 & $-10,5581$ \\
\hline $\mathrm{Q} 4$ & & & - & $6,7 \mathrm{E}-07$ & $7,2 \mathrm{E}-01$ & $\mathrm{Q} 4$ & & & - & 0,0113 & $-8,0377$ \\
\hline$\overline{\mathrm{Q} 5}$ & & & & - & $7,5 \mathrm{E}-01$ & Q5 & & & & - & $-20,8244$ \\
\hline \multicolumn{6}{|c|}{ Debiting coefficient } & \multicolumn{6}{|c|}{ Profit/price trend } \\
\hline & $\mathrm{Q} 2$ & Q3 & $\mathrm{Q} 4$ & Q5 & \multicolumn{2}{|c|}{ AVERAGE } & $\mathrm{Q} 2$ & Q3 & Q4 & Q5 & AVERAGE \\
\hline Q1 & 0,0650 & 0,2102 & 0,0828 & 0,0226 & 78,732 & Q1 & 0,0895 & 0,0444 & 0,2252 & 0,2738 & 0,0208 \\
\hline $\mathrm{Q} 2$ & - & 0,4212 & 0,2605 & 0,1721 & 149,884 & Q2 & - & 0,3272 & 0,1547 & 0,0051 & 0,0090 \\
\hline Q3 & & - & 0,4087 & 0,1577 & 135,827 & Q3 & & - & 0,0445 & 0,0009 & 0,0071 \\
\hline $\mathrm{Q} 4$ & & & - & 0,0700 & 121,384 & Q4 & & & - & 0,0379 & 0,0142 \\
\hline Q5 & & & & - & 232,470 & Q5 & & & & - & 0,0265 \\
\hline \multicolumn{6}{|c|}{ Debiting coefficient trend } & \multicolumn{6}{|c|}{ Dividends/price ratio } \\
\hline & Q2 & \begin{tabular}{|l|} 
Q3 \\
\end{tabular} & $\mathrm{Q} 4$ & Q5 & \multicolumn{2}{|c|}{ AVERAGE } & $\mathrm{Q} 2$ & Q3 & Q4 & Q5 & AVERAGE \\
\hline Q1 & 0,0025 & 0,0031 & 0,0061 & 0,2091 & 0,1255 & Q1 & 0,0001 & 0,0000 & 0,0000 & 0,0957 & 4,0444 \\
\hline $\mathrm{Q} 2$ & - & 0,4111 & 0,3674 & 0,0054 & 0,0217 & $\mathrm{Q} 2$ & - & 0,2852 & 0,1172 & 0,1387 & 5,6354 \\
\hline Q3 & & - & 0,4282 & 0,0068 & 0,0240 & Q3 & & - & 0,2560 & 0,1439 & 5,8707 \\
\hline $\mathrm{Q} 4$ & & & - & 0,0168 & 0,0271 & $\mathrm{Q} 4$ & & & - & 0,1521 & 6,1201 \\
\hline Q5 & & & & - & 0,0883 & Q5 & & & & - & 13,8683 \\
\hline \multicolumn{6}{|c|}{ Market capitalization } & \multicolumn{6}{|c|}{ Dividends/price trend } \\
\hline & $\mathrm{Q} 2$ & Q3 & $\mathrm{Q} 4$ & $\mathrm{Q} 5$ & AVERAG & & $\mathrm{Q} 2$ & Q3 & Q4 & Q5 & AVERAG \\
\hline Q1 & 0,0137 & 0,0050 & $1,3 \mathrm{E}-06$ & 0,0050 & $1,5 \mathrm{E}+09$ & Q1 & 0,0566 & 0,0383 & 0,0714 & 0,0109 & 0,0018 \\
\hline $\mathrm{Q} 2$ & - & 0,2747 & 0,0010 & 0,1807 & $2 \mathrm{E}+09$ & Q2 & - & 0,4812 & 0,3902 & 0,1758 & 0,0030 \\
\hline Q3 & & - & 0,0067 & 0,3306 & $2,1 \mathrm{E}+09$ & Q3 & & - & 0,3572 & 0,1746 & 0,0030 \\
\hline Q4 & & & - & 0,0433 & $2,7 \mathrm{E}+09$ & Q4 & & & - & 0,1156 & 0,0027 \\
\hline Q5 & & & & - & $2,2 \mathrm{E}+09$ & Q5 & & & & - & 0,0040 \\
\hline
\end{tabular}

